\section{"Whispers through the trees"}

The challenge which every profession faces is whether or not its members can be kept in a state of high professional competence. This involves a mental alertness and awareness about what is going on in each person's specific line of endeavour. The forest entomologist cannot be expected to know what the latest developments in seedling container production are, but he should know what they are in his own field and equally well he should know when he is out of his own area of competence.

In any group of people and in nearly every activity there are always some, a few, sometimes many, who like stones sink to the bottom where they flows over them. They may roll slightly when an infrequent strong current of some endeavour reaches down and overcomes their inertia but otherwise they remain slowly gathering the encrustation of a lifetime's silt - the process of professional sedimentation.

The main purpose of any professional group or institution is not only to maintain a minimum standard of activity or practice but also to improve practice, to assist with innovation and perhaps most importantly to ensure that the vital spirit of professionalism is maintained within its membership. This means that there must be a continual exposure - a churning of the waters of professional practice so that those who would sink of their own weight are forced into motion - to new stimuli, and to a kind of professional weathering which if it does not prevent completely, at least militates against a complete blanket by sediment. rest quietly as the stream of life
Unfortunately professions, educational institutions and government bureaucracies have a tendency to consider that if they have defined their goals, then all that is necessary is some rational program of implementation. This is akin to digging a canal for the placid movement of water from $A$ to B. Examples abound - a school of forestry sets down a curriculum; a government whose goal is to manage forest lands or natural resources proceeds to reorganize; professional associations concerned ostensibly with levels of practice seek to do it by means of entrance qualifications and the payments of annual dues!

There is nothing wrong with stating objectives and then planning the business of attaining them, but there is something else which is more important. It is to ensure that the very processes and activities of the organization stimulate and enhance the professional agility of its members. Most institutions do not challenge; they stultify. They aggregate mediocrity; the membership can only conceive of activity governed by regulation - a static achievement of goals. There is a place for the routine, the codification, but it must be kept in a subservient role to the stimulation of the mind.

When a profession and the institutions in which its members serve are not continually active in ensuring stimulation, innovation and challenge, then they are defunct. A profession whose members are largely employed by public institutions and large private corporations is particularly susceptible to such a condition.

Nemorensis
In order to convince my superior of the necessity to attend this meeting I have to attach the agenda of the meeting, stating topics, speakers and excursions. Emphasis is placed on professionalism and value to my organization.

The lighthearted, almost stag partylike announcement of the meeting has made it difficult for me to convince my superior that serious professional presentations are made. Such words as: land of rape and honeys, top hatest city, wild game(s) *Ladies specials, etc. give an entirely foolish impression to outsiders. I would appreciate it if you would draft a sincere and appropriate announcement, suitable for attachment to my request for funding this trip to Prince Albert.

Dear

I am sorry if the "lighthearted announcement" about our Annual Meeting in Prince Albert in October of this year has caused you any inconvenience.

The reference to the "top hatest city" is of course, because Prince Albert has always used the Prince Albert hat as its trade mark. The reference to "rape and honeys" is of course, as you know, taken from Diefenbaker's speech and therefore, allowable I believe. The reference to "wild game(s)" refers to a wild game dinner put on by the Saskatchewan government so I don't really think you can run that one down. The reference to "Ladies specials" applies of course, as is usual, to the Ladies program. For a great many years the CIF has put on one of the best Ladies programs of any Forestry Conference and we certainly don't mean to take it away from them.

As to your superior's thoughts on the matter, perhaps he is not acquainted with some of the names of speakers, but I believe if he looks at them more closely, he will realize that there will be a great deal of forestry information and discussion of real value to Canada in the program. The proposed tours, in themselves, are well worth the trip to Prince Albert. As a matter of fact, the ERTS Radar Site in itself is worth a trip to Prince Albert.

Perhaps you and your superior have not attended past meetings of the Canadian Institute of Forestry. I assure you that there is much serious discussion, a great deal in the area of continued education and of course, as anyone knows, the social events are decorous, but certainly not staid. Possibly you could show your superior the report of the 64th Annual Meeting of the CIF at Fredericton. This was included in Volume 48, Number 5, October 1972 edition of The Forestry Chronicle. I believe this in itself would be convincing.

You will very shortly receive more information on the Annual Meeting and I would be surprised if the value offered did not convince your superior that he should attend also.

Yours sincerely

A. G. Racey, R.P.F. 


\section{In my opinion}

In my opinion the popular approach in assigning use on forested areas particularly is also wrong, i.e.. separate use for separate areas. Recreation of all types can be made to be compatible with removing trees that should be harvested or vice versa. I believe that a forested area should be handled by those who have a sense of husbandry. Most of our forested areas must be managed whether the present day city dwellers, i.e., prospective recreationist, like it or not, because there are too few acres of livable land in the world for the population to do otherwise. The Canadian Institute of Forestry Forest Land Policy statement has, in my opinion, the right approach in stating that "Most forest land can satisfy a number of uses, including the growing and harvesting of timber, and the providing of a variety of recreation experiences, clean water and an attractive environment", managed properly of course. Surely no one in their right senses expects trees of a forest to be left standing until they become decadent, particularly if fire is to be kept out. It should be left to the forester to choose the type of silviculture to be practised, particularly in certain areas of natural beauty and, therefore, more attractive to urban dwellers. It should be economically possible to introduce into logging systems, techniques without the use of heavy machinery which would enhance the scenery. I understand the Swiss use methods which they call naturalistic silviculture, which include cutting systems which are fully adapted to local conditions. The forest never ceases to be "forest". The complicated biocentric relationships of this system in their country have shown themselves to be highly stable. The lasting protection and social benefits of the naturally managed forests in mountainous areas are not to be underestimated. In Switzerland, the disadvantages of this system are small compared with its advantages. But considerable silvicultural knowledge is required.

There is no question that nature-love is in a large degree a genuine religious experience of extreme importance to those who experience it. We, therefore, have no moral right to restrict nor disparage it. And even if we take a rationalist view and deny the presence of a divine element, it remains an experience of value and importance and should always be considered and allowed for. This can be done, in my opinion, without the necessity of setting aside large forested areas as so-called "wilderness". / From a brief by R. D. LOOMIS to Alberta's Environment Conservation Authority.

\section{* 40 \& 20 years $*$}

September 1933. However much the annual meeting of the (Canadian) Society (of Forest Engineers) and the Forestry Chronicle have done to promote the purpose of the Society, it is evident that the third object has been greatly neglected. The fault does not lie with the founders of the Society or in the constitution which they wrote. The fault lies with the present membership. Each day furnishes an opportunity to make the Society as alive and purposeful as on the day of its creation. The founders knew that the discussion of technical and professional topics, the promotion of better acquaintanceship among the members and the cultivation of esprit de corps were good things at that time, but they also contemplated that from time to time further steps must be taken to promote the interests of forestry in Canada. We have not taken those steps. We have rested upon the efforts and energy of those who founded the Society, accepted the benefits of membership, and expected the Society through some strange, unseen power to promote the interests of the profession without effort on the part of the membership. That the Society cannot do. There must be effort on the part of the membership, and there must be direction of membership effort if there is to be progress./ Avery

September 1953. The past decade has seen a demand for foresters and forest engineers in Canada that has outstripped that of probably any other decade in our country's history. This situation will continue over the long run, with only temporary rising and falling in the demand curve based on economic conditions. Industry prefers forest engineers for many jobs, but where the supply has not met the demand, other lines of training have stepped in to fill the gap. Pure foresters and technicians from specific fields of science have tended to be the main need of the government services.

The whole story of forest employment reads like the days of the gold rush or the oil booms, and will just as surely be followed by the period of "digging-in" and full stability.

Now our needs are for basic forestry - tomorrow they will have expanded to include the many refinements of the profession. Even today we do not have enough highly trained personnel to make the "research team" approach practical for all our problems. Unless we prepare to meet the need of our immediate future - the need for advanced and specialized training in post-graduate study - we are going to wake up to find an intellectual vacuum in our advanced technical fields. 


\section{Forestry is ...}

For Participation 13, readers were asked to send in either their own definition of forestry or the one (and source) that they considered best.

Although not entered for Participation 13, we include this statement prepared by the fledgling Association of University Forestry Schools of Canada: Modern forestry. . .

. . . is the science, business and art of managing and conserving forests and associated lands for continuing economic, social and environmental benefit;

. . . involves the balanced management of forest resources for optimum yields of wood products, abundant wildlife, plentiful supplies of pure water, attractive scenic and recreational environments in both wildland and urban settings, and a variety of other services and products;

...draws upon knowledge and expertise from many disciplines and other professions;

... plays a vital role in the development and implementation of techniques for the management of forest resources.
E. W. March, Editor/Secretary of the Commonwealth Forestry Association (London, England) wrote: In the United Kingdom half our graduate foresters are Bachelors of Arts and the other half Bachelors of Science. For more than 40 years I have always defined forestry as The art or science of putting a piece of forest or potential forest area to its optimum use.

Bruce Devitt's (Victoria, B.C.) definition is: Forestry: an holistic stewardship of the forest environment.

J. V. Thirgood (Vancouver, B.C.) likes Sir Harry Champion's definition: Forestry is an art requiring observation and judgement, relying on the sciences to no small degree but not exclusively on them.

And with a lighter touch, Art Racey (Senneville, Quebec) submitted: Forestry is the manipulation of forests and sometimes of foresters. It is rather like sex. It may be productive, but is almost always aesthetic and certainly recreational (for those truly interested). The economics of the practice will, of course, continue to be discussed from various angles by all those concerned.

\section{A choice for Participation 15}

If you were banished to an island without any trees but were allowed to take only 3 tree seeds with you, which ones would you take, and why did you select them?
Send your participation to: The Editor, The Forestry Chronicle, 17 Elizabeth St. N., Richmond Hill, Ontario, L4C 4N4. Deadline: November 30 . Offerings will appear in February.

Stark, bleak and dour in winter.

\section{SWAN SONG?}

The following Forest Sketches were written in 1927 when I was in a romantic mood. Now that I am over 80 years of age I still have an interest in trees. White spruce. Black Imperial, rooted in the past, immoveable before the advancing tide of times; finally torn from its soil by revolutionary fire or axe. So the Swiss guard at Versailles were cut down but did not yield.

Black spruce. Ragged, hungry revolutionists, heart-filled with ill understood impatience. The mob marching on Versailles, scythe and bill-hook on shoulder. Leaning, struggling against things as they are.

Jack pine. Jack was a sad fellow, a prodigal son of a good family, he has seen the world, fed on husks, and has come back a little ragged and gnarled but has some good sturdy quality in him still.

White pine. The aristocrat of trees, blue-blood to the leaf tips. Scion of a thousand generations of dominance. Natural dignity and grace, with culture.

Tamarack. A puzzling dual nature. Radiant with tenderness opening carmine flower buds and dainty leaves in spring.
Aspen. Populus tremuloides, daughter of the people. Fluttering tender maiden, seeking the light, seeking the world. Tenderest fairy shimmer of virgin green in spring.

Paper birch. Sad-eyed virgin, weeping she knows not why. Graceful, aloof, cloistered.

C. B. Gill

Winnipeg, Man.

\section{A LATE PECULIARITY}

Your fine publication passes over many desks before it makes all the rounds at our Station. As a result, often quite some time passes before all of us have had a chance to see it, which is precisely the dilemma I find myself in at the present time.

I am fully aware that the expiration date for "Participation 12 a peculiarity" has long since passed. However, as a possible matter of general interest, I thought I'd send along the enclosed snapshots anyway.

They depict an unusual deformity I ran into in 1969 while working on Roan Mountain in western North $\mathrm{Ca}$ rolina. The tree is a small Fraser fir,

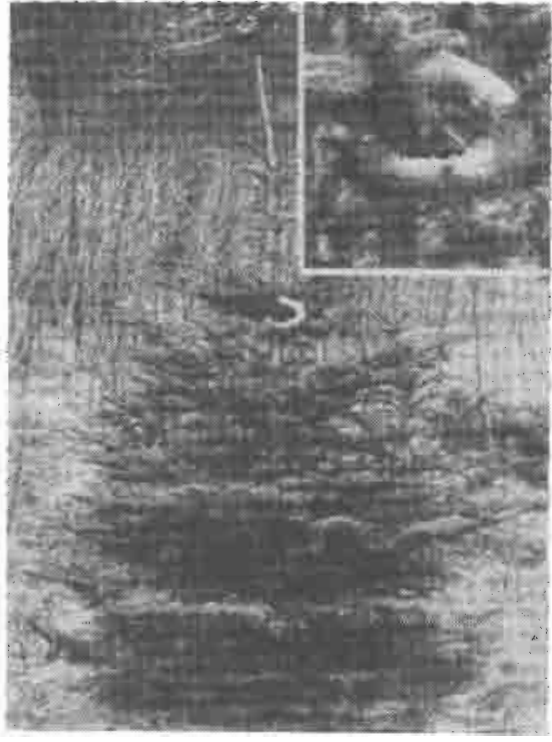

Abies fraseri (Pursh) Poire., and at first glance appears to be as much pretzel as it is tree. A closer look revealed that the mainstem had made a complete loop backwards before resuming its upward growth. As can be seen from the length of the terminal, the fir's subsequent rate of growth does not seem to have suffered unduly from its earlier contortions.

Fraser fir is highly prized in our state as a Christmas tree. In 1971 when I last went to the spot where this tree was growing, it had been cut down and removed. I like to think someone carried it off around Christmas-time because the "loop" provided just the right place in which to hang that special ornament.

Gerry Fedde

Southern Forestry Experiment Station Research Triangle Park, N.C. 